\title{
La transmisibilidad del crédito indemnizatorio por daño moral de la víctima fallecida: análisis del caso chileno*
}

\author{
The Survival of the Right to Claim Non-Pecuniary Losses Suffered by the Victim After her Death: Analysis of the \\ Chilean Case
}

Susana Espada Mallorquin a

Universidad Adolfo Ibánez, Chile

DOI: https://doi.org/10.11144/Javeriana.vj69.tcid

susana.espada@uai.cl

ORCID: https://orcid.org/0000-0001-9929-320X

Recibido: 02 Septiembre 2019

Alberto Pino Embart

Aceptado: 16 Octubre 2019

Universidad Adolfo Ibáñez, Chile

ORCID: https://orcid.org/0000-0003-2066-6611

Publicado: 15 Agosto 2020

\section{Resumen:}

Este artículo analiza la procedencia de la acción indemnizatoria por el daño moral sufrido por la víctima directa, ejercida por los herederos en el caso de su fallecimiento. Se considera especialmente el caso del derecho chileno, donde la jurisprudencia reciente ha ido cambiando desde la tradicional postura de la intransmisibilidad a la transmisibilidad de la acción en los casos en los cuales la víctima alcanzó a sobrevivir al menos un instante. Se consideran los méritos de las tesis que se han planteado al respecto, y se defiende la tesis de la transmisibilidad de la acción, para luego plantear algunas dificultades de esta tesis.

Palabras clave: daño moral, transmisibilidad, crédito indemnizatorio, herencia.

\section{Abstract:}

This article analyzes the origin of the compensation action for the moral damage suffered by the direct victim, exercised by the heirs in the event of the victim's death. The Chilean case will especially be considered, where recent case law has been changing from the traditional view, to accepting the survival of the right in cases in which the victim survived the tort at least a moment before her death. The arguments against and in favor of these theses are discussed, defending the thesis of the survival of the action. Finally, some difficulties that arise as a consequence of the survival of the right are analyzed.

Keywords: non-pecuniary damages, survival of the action, damages, estate.

\section{Introducción}

En muchos ordenamientos jurídicos, la pertinencia de la indemnización del daño moral a la víctima ha causado suspicacias tanto a la doctrina como a la jurisprudencia. Si bien podríamos afirmar que actualmente en la mayoría de los países estudiados dicha controversia ha sido superada, lo cierto es que en aquellos casos en los que, producido el daño moral, la víctima fallece antes de que se dicte sentencia indemnizatoria o incluso antes de interponer ningún tipo de acción, la pregunta sobre la transmisibilidad hereditaria del daño moral del causante a sus herederos reabre numerosos interrogantes sobre el fundamento de dicho daño.

En el presente artículo se pretende dar cuenta de los distintos interrogantes que plantea la transmisibilidad hereditaria del daño moral de la víctima fallecida, manifestar una opinión respecto a la misma y analizar las consecuencias jurídicas de dicha opción. El estudio tomará como referencia esencial el ordenamiento chileno, sin perjuicio que, al utilizar la metodología funcionalista del método comparado, se tendrá presente la experiencia doctrinal, jurisprudencial y legal en otros países, fundamentalmente europeos y latinoamericanos, que se han tenido que enfrentar al mismo problema que el sistema chileno ${ }^{1}$.

Notas de autor

\footnotetext{
a Autora de correspondencia. Correo electrónico: susana.espada@uai.cl
} 


\section{Determinación del daño moral transmisible}

En primer lugar, la transmisibilidad hereditaria se define según el artículo 1097 del Código Civil chileno (en adelante CC) como "los asignatarios a título universal, con cualquier palabra que se les llame, y aunque en el testamento se les califique como legatarios, son herederos y representan a la persona del testador para sucederle en todos sus derechos y obligaciones transmisibles"2. De igual forma, en el artículo $951 \mathrm{CC}$ se dispone que se es heredero a título universal "cuando se sucede al difunto en todos los bienes, obligaciones y derechos transmisibles, o en una cuota de ellos, como la mitad, un tercio o quinto". Se ha señalado que sólo se van a transmitir los bienes, acciones, derechos y obligaciones de carácter patrimonial y no aquellos de naturaleza extrapatrimonial ${ }^{3}$. Por lo tanto, solo los herederos se van a subrogar en la posición del causante respecto de aquellas obligaciones que sean transmisibles y en ningún caso en aquellas cuya naturaleza sea personalísima.

Hecha esta aclaración, respecto del daño moral también es preciso determinar a qué tipo de daño nos estamos refiriendo para poder plantear su transmisibilidad. En los casos en los que el hecho culpable de un tercero tiene como consecuencia el fallecimiento de la víctima, es esencial tener presente que, desde la perspectiva del perjuicio moral (personal) producido, lo más probable es que haya más de un sujeto afectado y que el perjuicio resarcible no es la muerte en sí misma. En nuestra opinión, si el fallecimiento es instantáneo, a la víctima no se le resarce el perjuicio que sufre por el hecho de morir $^{4}$, sino que a quien se resarce es al que la sufre realmente, esto es, a sus allegados más próximos en general, pues son ellos quienes padecen la desintegración familiar que genera su muerte (daño por rebote) ${ }^{5}$. Eso es distinto a aquellos casos en que la muerte no tenga lugar de forma instantánea o casi instantánea, sino que transcurra cierto tiempo entre el hecho dañoso y el fallecimiento, siendo el lapso de tiempo suficiente para que la víctima sea la que sufra perjuicios resarcibles ${ }^{6}$. Del resarcimiento de estos perjuicios y su transmisibilidad sucesoria es sobre lo que vamos a centrarnos.

En los casos de muerte diferida, el perjudicado sufre perjuicios mientras vive. Desde la comisión del ilícito civil hasta el fallecimiento, se generaría un crédito resarcitorio que compensase los perjuicios padecidos durante ese periodo. Luego, al fallecer, el crédito resarcitorio que se transmite a los herederos es el que corresponde a la compensación de dichos perjuicios y no a la de los causados por su propia muerte, que dan lugar a una acción distinta atribuida a los herederos o a los perjudicados por ella, considerados como víctimas por repercusión o rebote. Esta última acción corresponde a un crédito cuantitativa y cualitativamente distinto al que originariamente había o podía haber ejercido la víctima ${ }^{7}$. En nuestra opinión, se trata de créditos que tienen un objeto distinto, por lo que consideramos incorrecto afirmar que la transmisión hereditaria del crédito resarcitorio que la víctima había ejercido en vida excluye la acción resarcitoria (por los perjuicios propios de los familiares) para resarcir los perjuicios causados por la muerte ${ }^{8}$. Son perjuicios de diversa índole, por lo que no puede producirse un solapamiento entre sus indemnizaciones.

Al igual que autores como Martín Casals o Solé Feliú, entendemos que cuando se afirma la intransmisibilidad hereditaria del crédito resarcitorio en los casos de muerte instantánea y se admite en los casos de muerte diferida, es porque el primer caso hace referencia a los daños que la propia muerte causa y estos son los daños que originariamente adquieren los más allegados por ser quienes los sufren (daños por rebote). Sin embargo, el segundo caso hace referencia a los daños que la propia víctima sufrió entre su causación y el fallecimiento y cuyo resarcimiento, entendemos, es un crédito transmisible por vía sucesoria?

Por lo tanto, el daño moral sobre el que estamos cuestionando su transmisibilidad hereditaria tiene que ver con aquel daño que la víctima sufrió antes de fallecer. En este punto, y adelantando una idea que vamos a desarrollar posteriormente, si bien se sostiene la transmisibilidad hereditaria del crédito resarcitorio, no se hace de una forma absoluta. Es decir, el resarcimiento a la víctima fallecida queda condicionado al daño efectivamente padecido, de tal manera que solo va a poder transmitirse por herencia el crédito que corresponda a los perjuicios consumados, sin poder extenderse a los que no han podido consumarse. 
Es por ello que, como también lo han señalado algunos autores, la problemática de la transmisión mortis causa del crédito es diferente cuando el crédito resarcitorio ya ha sido reconocido que cuando no, pues en el primer caso ya lo tenemos cuantificado en su importe y en el segundo es indeterminado ${ }^{10}$.

Habiendo dilucidado cuál es el daño cuya transmisibilidad hereditaria estamos analizando, ahora lo que procede cuestionarse es su transmisibilidad y, para ello, es esencial precisar qué es lo que se transmite en la indemnización del daño moral de la víctima fallecida.

\section{Determinación del carácter transmisible del daño moral: Tesis vigentes}

Si regresamos a las reglas sucesorias, lo esencial va a ser determinar el carácter de transmisible de la indemnización del daño moral de la víctima. En este punto, no hay dudas respecto de la transmisibilidad de los créditos resarcitorios por daños materiales, contando con el respaldo expreso del Código Civil en su artículo 2315 (referido al daño en las cosas, pero se discute sobre la transmisibilidad de los que compensan daños personales o morales ${ }^{11}$.

Tradicionalmente en Chile se sostenía la transmisibilidad de la acción resarcitoria del daño moral sobre la base de la tesis de Alessandri, según la cual la acción es transmisible dado que la ley no la ha declarado intransmisible, siendo la regla general los mencionados artículos 951 y 1057 del CC, además, porque el artículo 2315 del CC no distingue entre los daños patrimoniales y extrapatrimoniales ${ }^{12}$. Por otro lado, concordamos con Medina Crespo, quien indica que esta discusión tiene un trasfondo más profundo: la oposición misma a la indemnización del daño moral, ya que una vez que la oposición radical se vuelve difícilmente defendible, se siguen buscando obstáculos a su reconocimiento ${ }^{13}$.

Dicho esto, resulta oportuno analizar con cierto detalle las que consideramos tres tesis principales en esta materia y que tienen su reflejo tanto en la doctrina como en la jurisprudencia. Por un lado, la tesis que defiende la intransmisibilidad absoluta de este daño, por el otro la denominada tesis de la transmisibilidad mitigada, que la admite sólo si el titular fallece tras haber ejercitado la acción indemnizatoria correspondiente, y finalmente la tesis favorable a la transmisibilidad hereditaria del daño moral de la víctima.

\section{La intransmisibilidad absoluta del daño moral mortis causa}

Podemos comenzar afirmando que esta es la tesis imperante durante los últimos años en Chile. Básicamente, lo que se defiende es la intransmisibilidad absoluta del crédito resarcitorio por daño moral a los herederos bajo el argumento esencial de que, como afecta a un derecho personalísimo, es intransmisible mortis causa. La idea que subyace es que el crédito resarcitorio generado por el daño moral es tan personal como el derecho quebrantado.

Según esta tesis, el derecho agredido y el crédito resarcitorio que surge de la agresión nociva quedan sometidos a un mismo estatuto en el que se inserta su intransmisibilidad mortis causa de forma consecuencial. Esta tesis considera que como el daño moral lo sufre sólo el que lo padece, este no puede trasladar sus padecimientos, es, por lo tanto, injusto que se transfiera su compensación. Se considera que el crédito resarcitorio correspondiente a un daño moral no nace como derecho pecuniario ordinario, sino como una pretensión encaminada a la reparación de una lesión ligada a intereses rigurosamente personales, por cuya razón se afirma su carácter personalísimo; sólo la víctima puede hacer valer ese crédito, por lo que se extingue junto a su titular. La muerte hace desaparecer el daño y, con ello, la necesidad de compensarlo judicialmente ${ }^{14}$.

A dicha argumentación se añade que, al fallecer el perjudicado, el resarcimiento del daño moral no puede cumplir ya la función que justifica su existencia, al carecer de sentido que sean los herederos los que se beneficien de forma desnaturalizada de ese crédito resarcitorio. La función satisfactiva del resarcimiento del 
daño moral no se cumple si la indemnización queda en manos de terceros ${ }^{15}$. Para esta tesis, el reconocimiento del crédito resarcitorio solo tiene sentido si compensa el daño personal de quien lo sufre a quien efectivamente lo sufrió. Se afirma que va en contra de la conciencia social que quien no sufre un atentado contra un bien de la personalidad pueda recibir el provecho económico de la reparación que se le habría otorgado al damnificado ${ }^{16}$; al no ser correcto que el daño sufrido por una persona en su esfera personal se vuelva un beneficio injustificado para otro, pues implica una mercantilización de la responsabilidad civil ${ }^{17}$.

También se ha sostenido que, en aquellos casos en los cuales la víctima directa sufre un daño moral y con posterioridad muere sin haber interpuesto una acción dirigida a obtener su resarcimiento, ello sería indicativo de una especie de renuncia por parte de la víctima o de un perdón del ofendido ${ }^{18}$. Por otra parte, más recientemente otros autores han planteado que la transmisibilidad de la acción indemnizatoria genera un riesgo de "doble pago" o acumulabilidad de acciones por un mismo daño, teniendo en cuenta las acciones que también podrían tener los herederos en su calidad de víctimas por rebote ${ }^{19}$.

Para concluir, esta tesis también sostiene que admitir la transmisibilidad de la indemnización por un daño que ya no es reparable para la víctima, sería tanto como entender que nos encontramos ante una especie de pena civil, lo que, de nuevo, desnaturaliza la noción de daño moral, otorgándole una finalidad punitiva que no le corresponde ${ }^{20}$.

En resumen, según la tesis de la intransmisibilidad lo más oportuno es negar de forma absoluta la transmisibilidad del crédito resarcitorio por daño moral por el carácter personalísimo del derecho quebrantado, el carácter personalísimo del crédito que nace de él, el carácter personalísimo de la compensación que proporciona la indemnización y el sentido punitivo de esta compensación de otorgarse ${ }^{21}$.

Esta tesis ha tenido reflejo en la jurisprudencia chilena. En este sentido, podemos destacar sentencias relativamente recientes como la Sentencia de la Corte Suprema de 27 de junio de 2007 (rol 309-2006) ${ }^{22}$, o los votos particulares de los ministros Valdés y Carreño en la Sentencia de la Corte Suprema de 30 de agosto de 2017 (rol 4670/2017) ${ }^{23}$ que, amparados en el carácter personal del daño moral, niegan la admisibilidad de su transmisión a los herederos ${ }^{24}$.

Sin embargo, por nuestra parte queremos señalar las principales críticas a los argumentos de la tesis de la intransmisibilidad. Al igual que otros autores, consideramos que esta postura confunde el estatuto de un derecho personalísimo, como es el derecho a la integridad, con otro derecho, como es el resarcimiento de los daños causados por agredir un derecho personalísimo ${ }^{25}$. Naturalmente, el derecho personalísimo no es transmisible a los herederos, pero el crédito resarcitorio nacido por el daño que se causa por su atentado constituye un derecho subjetivo patrimonial que se transmite a los herederos como cualquier otro crédito pecuniario. Los herederos no le suceden en sus daños, que son personalísimos y no trasmisibles, sino en su reparación patrimonial y que por esencia constituye un endoso al responsable. El crédito resarcitorio surge con el hecho dañoso, aunque su concreción cuantitativa tenga lugar necesariamente después ${ }^{26}$. Es evidente que el derecho a resarcir deriva de la lesión de un interés no patrimonial (integridad física o psicológica), pero su indemnización proporciona una utilidad patrimonial. Por ello, no sería reprobable, sino que estaría dentro de la lógica sucesoria que, si el titular del crédito resarcitorio derivado de la lesión de ese interés no ha alcanzado a obtenerlo en vida, sean sus sucesores patrimoniales los que lo obtengan ${ }^{27}$.

Medina señala la necesidad de distinguir en este punto entre el momento en el que nace el crédito resarcitorio que genera el daño original en virtud del hecho dañoso y el instante en que puede efectuarse su determinación cuantitativa. El crédito resarcitorio queda constituido en virtud del hecho dañoso el día en que éste tiene lugar, aunque su cuantificación se produzca en un momento posterior y, por ello, desde ese momento es transmisible ${ }^{28}$.

La otra objeción esencial a la transmisibilidad se funda en la afirmación de que dicha posibilidad otorgaría un carácter represivo o punitivo a la compensación de los daños morales. Cabe señalar que el rechazo a esta 
función punitiva o sancionatoria de la indemnización del daño moral no es compartido en forma unánime por la doctrina chilena y comparada ${ }^{29}$, y que, por lo demás, es posible constatar esta función de manera constante en la jurisprudencia chilena ${ }^{30}$. Aun aceptando que el daño moral tuviera un fundamento represivo, como señaló Domínguez, esta no sería la razón para negar la transmisibilidad hereditaria del crédito, sino la imposibilidad de su transmisibilidad pasiva, es decir, para negar que los herederos del responsable que fallece tengan que asumir un castigo que tendría que ser necesariamente de carácter personal ${ }^{31}$. En este sentido, la muerte de la víctima no borra la afrenta o agravio que se pretendería sancionar con la indemnización del daño moral $^{32}$.

Respecto a la afirmación de que es injusto que los herederos del perjudicado fallecido se beneficien de un importe que corresponde a la indemnización de un perjuicio que sólo el causante ha padecido, en realidad no es un argumento atendible, salvo que se pretenda poner en cuestión el propio derecho a la herencia. Esto es así en el sentido de que, en el caso de los herederos, estos tienen derecho a una asignación patrimonial por el mero hecho de ser herederos, con independencia de si contribuyeron o no a formar dicho patrimonio ${ }^{33}$.

Por otra parte, no parece razonable sostener que el solo hecho de que la víctima no haya interpuesto la acción indemnizatoria antes de morir implique necesariamente su renuncia a la acción. No puede hablarse de una renuncia de la acción sin que haya transcurrido siquiera el plazo de prescripción, y, por lo demás, el argumento se debilita en los casos en los que ha transcurrido poco tiempo entre la materialización del daño y la muerte de la víctima.

Por último, tal y como señalamos al comienzo de este artículo, no es conveniente confundir en esta discusión la transmisibilidad de la acción indemnizatoria del daño moral que corresponde a la víctima, con la indemnización del daño moral a las víctimas por rebote. Si bien es cierto que, ocurrida la muerte de la víctima, los herederos podrían demandar separadamente el daño sufrido por la víctima directa y el daño sufrido por ellos de forma indirecta, ello no constituye un doble pago, puesto que se trata de dos tipos de daños distintos. El primero de ellos corresponde al daño que directamente alcanzó a sufrir la víctima antes de morir, respecto al cual los herederos ejercerán la acción indemnizatoria en su calidad de continuadores de la personalidad jurídica de la víctima, mientras que el segundo tipo de daños lo ejercerán en razón del propio daño moral que han sufrido como consecuencia de la muerte de un ser querido. Por lo demás, la supuesta acumulabilidad de acciones o doble pago se produciría igualmente en caso de que la víctima haya alcanzado a interponer la acción indemnizatoria correspondiente antes de morir $^{34}$.

\section{La transmisibilidad limitada al ejercicio de la acción indemnizatoria en vida del causante}

Si proseguimos con el análisis de las tesis, tenemos aquella que modifica parcialmente la anterior pues parte de la intransmisibilidad, pero no de forma absoluta, ya que admite la posibilidad que el crédito resarcitorio se transmita mortis causa. Sin embargo, solo aplica en los casos en los que el perjudicado expresó en vida su voluntad de ejercer la acción reparatoria, o si la ejercitó y falleció en el transcurso del proceso antes de que se le reconociera el crédito ${ }^{35}$.

Esta tesis admite la consideración de que no estamos ante la transmisión del daño moral personal, sino del crédito resarcitorio, pero lo que afirma es que existe una presunción de abandono de dicho crédito cuando su titular no lo ha ejercido en vida. Esto sería así, incluso en los casos en los que aún no haya transcurrido el plazo de la prescripción extintiva. Si el perjudicado fallece sin haber ejercitado su acción resarcitoria, se presume su renuncia al ejercicio por su inactividad. Se niega la existencia de esta renuncia si el perjudicado ha realizado algún acto demostrativo de su voluntad de ejercicio, aunque no haya sido judicialmente, o se ha visto imposibilitado para hacerlo ${ }^{36}$. 
Por lo tanto, se sostiene que el daño moral sólo se patrimonializa cuando quien lo ha sufrido ha ejercitado la acción resarcitoria, produciéndose, solo en ese caso, la transmisibilidad hereditaria por el fallecimiento del titular que había optado por esa patrimonialización de su daño. Se ha señalado por parte de la doctrina que esta tesis en realidad responde al fenómeno de lo que se puede denominar imperio de la sucesión procesal, porque, en realidad, solo admite la transmisión hereditaria de los créditos resarcitorios en los casos de sucesión procesal; es decir, cuando el perjudicado que fallece, y había ejercitado su derecho resarcitorio antes de morir $^{37}$.

En nuestra opinión esta tesis es criticable, porque, como ya se puso de manifiesto anteriormente, consideramos que el crédito resarcitorio nace con el daño y por la acreditación del daño, sin que su nacimiento pueda ligarse a que el perjudicado manifieste de cualquier forma su voluntad de reclamar una indemnización o que ejercite la acción correspondiente que la haga efectiva. Entendemos que la circunstancia de que el perjudicado hubiera ejercitado la acción o no en vida no puede ser una condición necesaria a la sustancialidad del crédito y, por ello, a que éste surja. Además, procesalmente, solo es posible defender la sucesión en el proceso en la medida que el objeto del mismo sea transmisible mortis causa ${ }^{38}$.

A su vez, esta tesis está interpretando el silencio o falta de ejercicio de la acción del crédito como una manifestación de voluntad, de renuncia al derecho. Eso sería tanto como decir que ningún derecho subjetivo se puede transmitir mortis causa si no se ha solicitado su declaración judicial. La sucesión procesal no determina el derecho de los herederos, sino que es la herramienta del ejercicio del derecho preexistente. Por lo tanto, si el derecho no es transmisible (objeto litigioso) con independencia de que se haya iniciado o no el ejercicio de la acción, ésta se extinguirá, ya que en ese caso no será posible la sucesión en la relación jurídico-procesal ${ }^{39}$. Por lo demás, reiterando la postura de Alessandri mencionada más arriba en relación con el artículo 2315 del Código Civil, esta tesis de transmisibilidad limitada no explica las razones por las cuales, en el caso de los daños patrimoniales, la acción sí sería transmisible incluso sin haber sido ejercitada la acción por parte de la víctima antes de morir.

Para concluir la argumentación crítica a esta transmisibilidad limitada, queríamos detenernos en la afirmación según la cual defender dicha transmisibilidad de forma absoluta sería defender la concepción represiva de la responsabilidad civil. De hecho, autores como Navia han sostenido que esta postura intermedia que admite la transmisibilidad únicamente en los casos en los que la víctima hubiera ejercitado en vida su acción constituye "una especie de sucesión en la venganza emprendida" 40.

Sin embargo, en nuestra opinión, la función que cumple el resarcimiento de este daño moral no es represiva, pero tampoco satisfactiva como defienden las dos tesis anteriores. Entendemos que nos encontramos ante un proceso creciente de objetivización de los daños no patrimoniales, que considera que las pérdidas no patrimoniales por lesión de un tercero son indemnizables con una cantidad de dinero, con lo cual la principal función de la indemnización por daños no patrimoniales no compensa propiamente el daño causado, sino que provee a la víctima de equivalentes pecuniarios que permiten hacer más soportables los daños morales sufridos $^{41}$.

Dicho lo anterior, no podemos dejar de hacernos cargo de que en la jurisprudencia chilena reciente también tenemos sentencias que han acogido esta tesis de la transmisibilidad limitada. Así, la sentencia de la Corte Suprema de 30 de agosto de 2017 (rol 4670-2017), según la cual indica que lo que determina el carácter transmisible es que el heredero haya iniciado la correspondiente acción resarcitoria del daño moral por el fallecimiento de su marido atropellado ${ }^{42}$.

Finalmente, desde un punto de vista del derecho comparado, tendríamos que afirmar que en aquellos escasos países de Latinoamérica donde cuentan con una mención legislativa específica sobre este tema, la tesis de la transmisibilidad limitada a su reclamación previa parecería ser la predominante. Así en artículo 1916 del Código Civil del Distrito Federal de México -modificado en 1982- se determina que "la reparación [por daños morales] (...) solo pasa a los herederos de la víctima cuando esta haya intentado la acción en vida" ${ }^{43}$ 
o el reciente Código Civil y Comercial argentino (en vigor desde 2015), cuyo artículo 1741 que contempla la indemnización de las consecuencias no patrimoniales establece que "(...) la acción sólo se transmite a los sucesores universales del legitimado si es interpuesta por éste" ${ }^{\text {44 }}$, manteniendo sobre esto el mismo criterio establecido por el artículo 1078 del Código Civil derogado ${ }^{45}$.

\section{La transmisibilidad absoluta del daño moral mortis causa}

Para concluir este recorrido por las tesis vigentes sobre esta materia, tenemos la tesis de la transmisibilidad absoluta del daño moral mortis causa. Esta es la tesis que defendemos en el presente artículo, como se puede concluir, en parte, de los aspectos críticos señalados a las dos anteriores.

Se defiende esa transmisión hereditaria básicamente porque entendemos que no es el daño personal (lesión de la integridad) ni la acción para reclamarlo lo que se transmite a los herederos, sino el crédito que surge por su causación. Debido a se trata de un crédito resarcitorio de un daño preexistente antes del fallecimiento su carácter no es personalísimo, sino que es un crédito patrimonial ordinario transmisible inter vivos y mortis causa al integrarse en el caudal hereditario de la víctima fallecida habida cuenta que nace con el hecho dañoso, independientemente de que su determinación cuantitativa tenga lugar después ${ }^{46}$. La muerte del perjudicado no supone la extinción del crédito resarcitorio del que ya era titular la víctima fallecida, pues tal extinción sólo puede tener lugar si el derecho se deja prescribir (y el demandado opone la prescripción) o el perjudicado ha renunciado expresamente a su ejercicio. Así pues, el crédito resarcitorio de quien sufre un daño moral y fallece antes de que se le haya reconocido la pertinente indemnización (habiéndola reclamado o no) se transmite a los herederos; e igualmente, el crédito de quien resulta perjudicado por la muerte de un familiar y fallece antes de que se hubiera reconocido la indemnización también se transmite a sus herederos.

En nuestra opinión, no es sostenible defender que la falta de interposición en vida de una acción para ejercitar un derecho deba interpretarse necesariamente como una renuncia a dicho derecho y, por ello, sea intransmisible a los herederos. El crédito resarcitorio nace con el daño y en virtud de ese daño, su nacimiento y transmisión no puede ligarse al momento en el que la víctima exprese de cualquier forma su voluntad de reclamar o la ejercite efectivamente mediante la interposición de una acción indemnizatoria ${ }^{47}$. Por lo demás, reiteramos que no hay razones suficientes para regular de manera distinta sobre esta materia los daños patrimoniales de los daños extrapatrimoniales.

Finalmente, también es esencial dentro de esta teoría la concepción que se tiene sobre la función que se le atribuye al resarcimiento del daño moral. Si se entiende que quien sufre un daño moral no tiene una merma en su patrimonio y que, por ello, no hay una reducción de caudal relicto; los herederos nada pueden reclamar, ya que, si lo hicieran, se enriquecerían injustamente. Esta interpretación está en línea con la consideración de que la función de la indemnización es satisfactiva, pues de lo que trata es de dotar a la víctima de ciertos medios económicos suficientes con los que tenga satisfacciones suplementarias que compensen de algún modo el dolor y sufrimiento causado ${ }^{48}$.

Por nuestra parte, no consideramos que esta sea la función de la indemnización del daño moral, sino que su función es resarcitoria. Ante una pérdida no patrimonial, hoy en día, no se considera indecoroso entender que cabe una compensación económica. De hecho, la creciente objetivización del daño moral y la existencia de índices de relevancia del daño para su cuantificación son una muestra de que la función principal de esta indemnización es resarcir una pérdida injustificada de un valor no patrimonial con un equivalente pecuniario ${ }^{49}$. Por lo demás, las tesis de intransmisibilidad suelen insistir en el carácter personal del daño moral, asociándolo exclusivamente a la noción de pretium doloris, concepción que ha sido superada por la doctrina ${ }^{50}$. De ser así, es evidente que el régimen jurídico del crédito resarcitorio de un derecho personal, no es personal, sino que está afecto al régimen general de transmisión inter vivos y mortis causa como crédito patrimonial ordinario. Como crédito se integra en el caudal hereditario, con independencia de que su cuantificación se 
realice posteriormente, ya que la muerte del titular del crédito que ya estaba en su patrimonio no motiva su extinción. Por otra parte, el argumento según el cual la transmisibilidad de la acción indemnizatoria constituiría un enriquecimiento injustificado para los herederos es una petición de principios: el punto de la discusión se centra, precisamente, en determinar si el beneficio o enriquecimiento para los herederos tiene una causa jurídica que lo justifique. A nuestro juicio, la causa jurídica que lo justifica es la calidad de herederos que tienen estas personas.

Llegados a este punto, podemos destacar que existen varias sentencias en la jurisprudencia chilena reciente que han acogido la tesis de la transmisión absoluta. Así, podemos destacar la sentencia de la Corte Suprema de 27 de diciembre de 2016 (rol 33990-2016) que acogió la tesis de la transmisibilidad de la acción indemnizatoria del daño moral, que niega el carácter personalísimo de la acción ${ }^{51}$ o la sentencia de la Corte Suprema de 1 de marzo de 2018 (rol 27842-2017) que habla directamente de la transmisibilidad del crédito resarcitorio por daño moral de la víctima a los herederos con independencia de que esta hubiera o no entablado la acción resarcitoria ${ }^{52}$.

De igual forma, en la Corte Interamericana de Derechos Humanos existen sentencias favorables a dicha tesis $^{53}$, como por ejemplo la sentencia de 14 de septiembre de 1996, caso El Amparo vs. Venezuela ${ }^{54}$ o la sentencia de la Corte Interamericana de Derechos humanos de 27 de febrero de 2002, en el caso Trujillo Oroza vs. Bolivia ${ }^{55}$.

En el ámbito del derecho comparado, se podría afirmar que la tesis dominante es favorable a la transmisibilidad. Si bien es cierto que en pocos casos dicha transmisibilidad del daño moral es reconocida de forma expresa en el ordenamiento, de forma general, han evolucionado hacia esta opinión tanto la doctrina como la jurisprudencia ${ }^{56}$. Podemos mencionar especialmente el caso del derecho italiano, en el cual se ha admitido jurisprudencialmente la transmisibilidad de la acción desde principios del siglo XX, siempre y cuando exista un lapso de tiempo significativo entre la ocurrencia del ilícito y la muerte de la víctima, de manera tal que se pueda materializar el daño a la integridad psíquica ${ }^{57}$. A la misma conclusión se arriba en el derecho inglés, donde los herederos tienen derecho a reclamar los daños morales sufridos por la víctima durante un intervalo significativo entre el ilícito y la muerte, excluyendo el dolor momentáneo que sea parte del proceso de la muerte misma ${ }^{58}$.

Igualmente, cabe destacar el esfuerzo de proyectos unificadores de derecho en el ámbito europeo. Por un lado tenemos el artículo VI.-2:202 (2) (a) del Marco Común de Referencia (DCFR), cuyos comentarios ${ }^{59}$ señalan como regla general la transmisibilidad mortis causa de los daños morales a los herederos, salvo renuncia del fallecido a su reclamación; o los comentarios al artículo 10:301 de los Principios de Derecho Europeo de la Responsabilidad Civil (PETL), donde se afirma que si el fallecimiento no es instantáneo, los daños no patrimoniales sufridos antes del fallecimiento por el fallecido deberían transmitirse a sus herederos, eso sí, en estos principios se señala que ésta es una cuestión de derecho procesal ${ }^{60}$.

En síntesis, podríamos afirmar que la tendencia europea es a acoger la tesis de la transmisibilidad hereditaria del crédito resarcitorio, con independencia de que se hubiera ejercido la acción. Sin embargo, como ya se señaló previamente, en Latinoamérica la tendencia legislativa y jurisprudencial es a admitir dicha transmisión sólo en los casos en los que la víctima hubiera ejercitado la acción resarcitoria en vida, salvo en el caso de Colombia donde la jurisprudencia ha acogido la tesis de la transmisibilidad ${ }^{61}$, y la doctrina lo confirma señalando que "la acción hereditaria está encaminada a que los herederos del fallecido cobren, en condición de tales, los perjuicios sufridos por la víctima directa del daño, poco importa que esta hubiera o no iniciado la demanda en responsabilidad" ${ }^{62}$. También podemos agregar el caso del derecho uruguayo, donde la doctrina entiende que el derecho a la reparación del daño moral se transmite a los herederos, "haya o no promovido la víctima la correspondiente demanda ante los estrados judiciales" ${ }^{\text {"3 }}$. La misma conclusión puede encontrarse 
en la doctrina brasileña, que, ante la ausencia de una norma explícita en el Código Civil, se ha inclinado por la transmisibilidad de la acción siguiendo la doctrina francesa de los hermanos Mazeaud ${ }^{64}$.

\section{Los desafíos que implica acoger la tesis de la transmisibilidad hereditaria del daño moral}

En virtud de los argumentos anteriormente señalados, consideramos que el crédito resarcitorio del daño moral sufrido por la víctima es transmisible a los herederos del fallecido. No obstante, somos conscientes que sostener esta tesis plantea diferentes desafíos a la hora de su aplicación. Procederemos a analizar algunos de ellos.

\section{La forma de interponer la acción}

Dado que se sostiene que nos encontramos ante un crédito resarcitorio transmisible, una de las primeras preguntas que surgen al admitir la transmisibilidad hereditaria tiene que ver con la forma oportuna para hacerlo efectivo por parte de los herederos, ya que todos ellos tienen la legitimidad activa tras el fallecimiento ${ }^{65}$.

Si partimos por el caso más sencillo, esto es que la víctima sólo tiene un heredero o que todos actúan de forma conjunta en la reclamación, no existe problema, ya que él o ellos actuarán como continuadores de la persona del causante. Además, conforme a los artículos 1097 y 951 del Código Civil chileno podrá o podrán subrogarse en el ejercicio de la acción indemnizatoria para reclamarlo ${ }^{66}$.

El principal problema surgirá cuando cada heredero decida demandar de forma separada la cuota que le corresponde en dicho crédito resarcitorio. Por un lado, nos encontramos con el problema de la determinación de la cuantía del crédito -que enseguida abordaremos-, pero procesalmente cada heredero puede realizar una propuesta distinta de indemnización, así como de cuota correspondiente. En esos casos, en primer lugar y en virtud de lo establecido en el artículo 21 del Código de Procedimiento Civil, se podría emplazar al resto de los herederos que no han ejercido la acción, los cuales "si declaran su resolución de no adherirse, caducará su derecho; y si nada dicen dentro del término legal, les afectará el resultado del proceso, sin nueva citación. En este último caso podrán comparecer en cualquier estado del juicio, pero respetando todo lo obrado con anterioridad"67.

De no realizarse tal emplazamiento, el demandado podría solicitar la acumulación de autos (artículos 92 y ss. Código de Procedimiento Civil), pues existe una relación de conexión entre los juicios, dado que la acción emana de unos mismos hechos y el objeto del juicio (procedencia del crédito resarcitorio) es el mismo. Sin embargo, es cierto que, si dicha acumulación no se realiza por las partes y el juez, no puede instarla de oficio -porque no se conocen ambas demandas en el mismo tribunal-, podríamos encontrarnos con dos sentencias que otorgaran una cuota y cuantía distinta por el crédito resarcitorio del daño moral de la víctima.

\section{La cuantificación del crédito resarcitorio transmisible}

Debemos tener claro que el daño moral que tenemos que cuantificar es el que sufrió la víctima directa y no el daño por rebote de las víctimas indirectas. Partiendo de esa premisa, como ya hemos afirmado, el crédito resarcitorio se ha transmitido desde el momento del fallecimiento de la víctima, pero su cuantificación es posterior a su muerte. Por ello, sólo se podrá transmitir lo devengado, es decir, los perjuicios consumados, pero no aquellos futuros posible que la muerte truncó. Es evidente que nadie puede indemnizar perjuicios 
imposibles y mucho menos transmitir un crédito resarcitorio por ellos; por lo tanto, en estos casos en los que antes de llegar al reconocimiento se produce el fallecimiento y se transmite el crédito a los herederos, en el crédito no pueden incluirse beneficios de anticipo, porque el fallecimiento ya se ha producido. Como señala Medina, la responsabilidad sirve para resarcir perjuicios ciertos e hipotéticos dotados de verosimilitud, pero no cubre los perjuicios imposibles ${ }^{68}$.

¿Sobre cuáles serían estos daños morales? En los ejemplos de las sentencias de la Corte Suprema chilena donde se reconoció la transmisibilidad, se tiene en cuenta como daño moral resarcible la agonía por el agravamiento del estado de salud de la víctima durante el traslado al hospital, el pesar y dolor hasta su muerte, así como la fractura de su plan de vida ${ }^{69}$. De igual forma, en un caso de ahogamiento se consideró la existencia de daño moral en la impotencia y angustia de hundirse en la piscina, percibir el proceso de asfixia hasta perder la conciencia y, posteriormente, durante los procedimientos y tratamientos invasivos para reanimar a la víctima ${ }^{70}$.

Resulta oportuno en este punto relativo a la cuantificación, y partiendo de que la muerte no es instantánea, sino que media cierto período de tiempo en donde dicho dolor y sufrimiento se le producen a la víctima, sí es precisa la consciencia durante dicho periodo para que resulten resarcibles. En estos casos, los tribunales ingleses consideran que, si la víctima no está consciente o de encontrarse en coma, no hay sufrimiento consciente por su parte y, por ello, no hay un daño moral que le sea resarcible. Lo que sí se les indemniza es la pérdida de placeres sufrida por la víctima desde el accidente hasta su fallecimiento ${ }^{71}$. Reafirmando esta postura, resulta interesante un caso resuelto por la Audiencia Provincial de Soria ${ }^{72}$, en el cual el padre y madre de los demandantes fallecen a causa de un mismo accidente, pero el padre fallece al día siguiente que la madre. El Tribunal determina que los hijos no pueden demandar por el daño moral sufrido por el padre, puesto que este no alcanzó a tener conocimiento de la muerte de su mujer ${ }^{73}$.

Sin embargo, algunos autores han señalado que esta es una concepción del daño moral puramente subjetiva y que, como todo daño corporal, implica un atentado contra la dignidad de la persona (dimensión objetiva). El daño se produce independientemente de las sensaciones subjetivas de la víctima, al ser un atentado al bien salud, cuyo resarcimiento es transmisible a los herederos ${ }^{74}$. En este sentido, si aceptamos la tesis según la cual el daño moral no se centra exclusivamente en el pretium doloris, deberíamos desechar la exigencia del grado de consciencia de la víctima antes de morir. Por lo demás, la indemnización del daño moral para personas que se encuentran en estado vegetal o inconsciente es una discusión de larga data en el derecho comparado, donde la regla general pareciera ser la aceptación del daño moral en estos casos ${ }^{75}$.

Por último, cabe mencionar que respecto de la acción que ejercen los herederos por el daño moral directamente sufrido por el causante, no existe inconveniente alguno en cuanto a la aplicabilidad de la posible reducción en la indemnización por culpa de la víctima, al seguir la regla general del artículo 2330 del Código Civil.

\section{La prueba del daño moral sufrido por la víctima fallecida}

Lo señalado anteriormente no obsta el seguimiento de las reglas generales sobre la prueba del daño moral que la víctima directamente sufrió en el intervalo entre la comisión del ilícito extracontractual y su muerte. Así las cosas, debemos entender que los herederos tendrán la carga de probar la existencia de un daño moral sufrido directamente por la víctima, del mismo modo que la doctrina chilena entiende que el daño moral debe probarse en general ${ }^{76}$. Ahora bien, tratándose de una víctima que ha fallecido, dicha prueba deberá enfrentarse con evidentes dificultades, especialmente tratándose de la acreditación del pretium doloris. En este sentido, cobrarán especial relevancia las presunciones judiciales del artículo 426 del Código de Procedimiento Civil, que permitan tener por acreditado el daño moral a partir de antecedentes que sean suficientemente graves 
para presumirlo, y de manera fundada ${ }^{77}$. Así, por ejemplo, en el caso de la jurisprudencia chilena en el que la Corte Suprema acogió la transmisibilidad de la acción, se consideró que el hundirse y ahogarse en una piscina, junto con la realización de intentos por reanimar a la víctima, permiten tener por acreditada la existencia de daño moral $^{78}$.

\section{Conclusiones}

Si bien entendemos que la transmisibilidad de la acción indemnizatoria por daño moral es un asunto discutible, nos parece que hay argumentos convincentes a su favor, fundados tanto en el derecho positivo chileno como en el derecho comparado. Como hemos visto, la mayoría de los argumentos en contra de la transmisibilidad se fundan en concepciones sobre el daño moral que lo configuran como un derecho personalísimo, pero confundiendo la naturaleza personal del daño y la existencia de un crédito resarcitorio que ya ha ingresado al patrimonio de la víctima.

Por otra parte, la solución intermedia adoptada por algunas legislaciones latinoamericanas tampoco nos parece adecuada, puesto que tiende a asumir -injustamente en la mayoría de los casos- que la víctima ha renunciado su derecho a ejercitar la acción por el solo hecho de no haber interpuesto la demanda respectiva. Tampoco nos parece atendible la objeción según la cual, en caso de acogerse la transmisibilidad de la acción, esta se acumule ilegítimamente con el daño moral de las víctimas por rebote, ya que se trata claramente de dos daños distintos.

Por último, hemos abordado brevemente las implicaciones de acoger la tesis de la transmisibilidad en cuanto a la forma de interponer la acción entre los distintos herederos, la cuantificación del daño moral y su prueba. Si bien la transmisibilidad genera algunas dificultades desde el punto de vista de estas implicaciones, ello no introduce mayores dificultades de las que presenta el daño moral en general, como se puede apreciar respecto de su avaluación y prueba. Es de esperar, en consecuencia, que la jurisprudencia chilena no retroceda en esta postura que consideramos tiene sustento teórico suficiente, y se concentre en aspectos más problemáticos, como la forma de determinar la cuantía del daño moral en estos casos, y determinar con precisión la prueba y las presunciones admisibles del mismo en casos donde la víctima ya ha fallecido.

\section{Referencias}

Adriano De Cupis, El daño: Teoría general de la responsabilidad civil (2.. ed., Bosch, 2011).

Alma M. Rodríguez Guitián, Indemnización por causa de muerte: análisis de los ordenamientos jurídicos inglés y español, 2 Indret, n. ${ }^{\circ} 7,1-53$ (2005). https://indret.com/wp-content/themes/indret/pdf/1138_es.pdf

Arturo Alessandri Rodríguez, De la responsabilidad extracontractual en el derecho civil chileno (Editorial Jurídica de Chile, 2005).

Audiencia Provincial Sección 1 de Soria (España). Sentencia 00013/2014, 14 de abril de 2014.

Carmen Domínguez Hidalgo, El daño moral (Editorial Jurídica de Chile, 2000).

Claudia Mejías Alonzo, Posibles límites al daño por repercusión o rebote, en Estudios de Derecho Civil X, 873-888

(Álvaro Vidal Olivares, Gonzalo Severín Fuster \& Claudia Mejías Alonzo coords., Thomson Reuters, 2015).

Co\#digo Civil de Chile [CC]. Ley de 14 de diciembre de 1855. Art. 1552. 1 de enero de 1857 (Chile).

Código Civil Federal de México. Decretos de 7 de enero y 7 de diciembre de 1926, y 3 de enero de 1928 (México).

Código Civil y Comercial Unificado de la Nación. Ley 26994 de 2014.7 de octubre de 2014 (Argentina).

Código de Procedimiento Civil de la República de Chile. Ley 1552 del 28 de agosto de 1902 (Chile).

Cornelis C. Van Dam, European Tort Law (2.. ed., Oxford University Press, 2013). 
Corte Interamericana de Derechos Humanos. Caso Serie C No. 28. "El Amparo vs. Venezuela”, 14 de septiembre de 1996.

Corte Interamericana de Derechos Humanos. Caso Serie C No. 92. “Trujillo Oroza vs. Bolivia”, 27 de febrero de 2002.

Corte Suprema de Chile. Rol n. 27842-2017. “Cárcarmo Cárcamo con Ícono División Turismo S.A., 1 de marzo de 2018.

Corte Suprema de Chile. Rol n. $309-2006$. "Porman Barahona con Pesquera Bío Bío S.A.”, 27 de junio de 2007.

Corte Suprema de Chile. Rol n. 33990-2016. “Quezada Gallardo con Colmenares Warner Limitada”, 27 de diciembre de 2016.

Corte Suprema de Chile. Rol n. 4670-2017. “Culaciati Erwenne con Muñoz Barrientos”, 30 de agosto de 2017.

Cristián Aedo Barrena, Responsabilidad extracontractual (Librotecnia, 2006).

Edwin Peel \& James Goudkamp, Winfield \& Jolowicz on Tort (19.. ed., Sweet \& Maxwell, 2014).

Enrique Barros Bourie, Tratado de responsabilidad extracontractual (Editorial Jurídica de Chile, 2006).

Esteban Pereira Fredes, Un alegato a favor de las consideraciones punitivas en el derecho privado, Revista de Derecho Escuela de Postgrado, n. ${ }^{\circ}$ 7, 61-78 (2015). https://doi.org/10.5354/0719-5516.2015.37264

Esther Gómez Calle, Los sujetos de la responsabilidad civil. La responsabilidad por hecho ajeno, en Tratado de Responsabilidad civil, 461-538 (L. Fernando Reglero Campos coord., Aranzadi, 2007).

European Group on Tort Law, Principios de Derecho europeo de la responsabilidad civil (traducción REDPEC, Martín Casals coord., Aranzadi, 2008).

Fabián Elorriaga De Bonis, Novedades judiciales en torno al daño moral por repercusión, en Estudios de Derecho civil IX, 229-245 (Hernán Corral Talciani \& María Sara Rodríguez Pinto coords., Abeledo Perrot, 2011).

Federico de Castro y Bravo, La indemnización por causa de muerte, 1956 Anuario de Derecho Civil, n. ${ }^{\circ}$ 2, 451-504 (1956).

Federico Navia Arroyo, Del daño moral al daño fisiológico ¿Una evolución real?, 4 Ensayos (2000).

Fernando Fueyo Laneri, De nuevo sobre el daño extrapatrimonial y su resarcibilidad (Universidad de los Andes, 1972).

Fernando Fueyo Laneri, Instituciones de derecho civil moderno (Editorial Jurídica de Chile, 1990).

Fernando Pantaleón Prieto, Diálogo sobre la indemnización por causa de muerte, 36 Anuario de Derecho civil, n. ${ }^{\circ}$, 1567-1585 (1983). https://dialnet.unirioja.es/servlet/articulo?codigo $=46609$

Fernando Pantaleón Prieto, La indemnización por causa de lesiones o de muerte, 42 Anuario de Derecho Civil, n. ${ }^{\circ}$, 613-652 (1989). https://dialnet.unirioja.es/servlet/articulo?codigo $=2769429$

Gerardo Von Wichmann Rovira, La responsabilidad extracontractual o derecho de daños, en Instituciones de Derecho privado (Juan Francisco Delgado De Miguel coord., Civitas, Madrid, 2003).

Hernán Corral Talciani, Concurrencia de acciones de responsabilidad civil contractual y extracontractual en los daños causados por accidentes de trabajo, 14 Revista Chilena de Derecho Privado, 69-107 (2010). https://doi.org/10.4 067/S0718-80722010000100003

Hernán Corral Talciani, Lecciones de responsabilidad civil extracontractual (2.a ed., Thomson Reuters, 2013).

Hernán Corral Talciani, Lecciones de responsabilidad extracontractual (Editorial Jurídica de Chile, 2003).

Hernán Corral Talciani, Una vez más sobre la transmisibilidad del daño moral [en línea], El Mercurio Legal, (11 de enero, 2017). http://www.elmercurio.com/Legal/Noticias/Analisis-Juridico/2017/01/11/Una-vez-mas-sobre -la-transmisibilidad-de-la-indemnizacion-por-dano-moral.aspx

Javier Tamayo Jaramillo, Tratado de responsabilidad civil (2.. ed., Legis, 2007).

Jorge F. Calderón Gamboa, La reparación integral en la Jurisprudencia de la Corte Interamericana de Derecho Humanos: Estándares aplicables al nuevo paradigma mexicano (Instituto de Investigaciones Jurídicas, 2013).

Jorge Gamarra, Tratado de Derecho Civil Uruguayo. Responsabilidad Extracontractual (Fundación de Cultura Universitaria, 2012). 
Manuel Barría Paredes, Algunos aspectos que plantea la tesis de la transmisibilidad de la acción indemnizatoria por daño moral, en Estudios de Derecho Civil XIII, 673-688 (Claudia Bahamondes Oyarzún, Leonor Etcheberry Court \& Carlos Pizarro Wilson eds., Thomson Reuters, 2018).

Manuel Rebolledo Puig, Capacidad, representación y legitimación del reclamante en el proceso administrativo de responsabilidad patrimonial, 16 Revista Española de la Función pública, 77 (2011).

Marcelo Barrientos Zamorano, Del daño moral al daño extrapatrimonial: La superación del pretium doloris, 35 Revista Chilena de Derecho, 85-106 (2008). https://doi.org/10.4067/S0718-34372008000100004

Mariano Medina Crespo, Transmisibilidad hereditaria del crédito resarcitorio por daños corporales (Bosch, 2013).

Mariano Yzquierdo Tolsada, Sistema de responsabilidad contractual y extracontractual (Dykinson, 2001).

Mário Moacyr Porto, Dano moral II, en Doutrinas Essenciais, 703-710 (Rui Stoco ed., Thomson Reuters, 2015).

Miquel Martín Casals, Conceptos prejudiciales (heads of damage) en la indemnización por muerte y lesiones personales en Europa, 2 Indret, 1-48 (2013). https://www.raco.cat/index.php/InDret/article/download/264209/351862

Miquel Martín Casals \& Josep Solé Feliú, El daño moral, en Derecho privado europeo, 857-881 (Sergio Cámara Lapuente coord., Colex, 2003).

Pablo Rodríguez Grez, Responsabilidad extracontractual (2.. ed., Editorial Jurídica de Chile, Santiago, 2010).

Paolo Sanna, The Recoverability of the Loss of the Right to Life per se: A Brief European Overview, 4 The Italian Law Journal, n. ${ }^{\circ}$ 1, 149-167 (2018). https://www.theitalianlawjournal.it/sanna/

Pilar Domínguez Martínez, Daño moral derivado de muerte y de lesiones corporales, en El daño moral y su cuantificación, 307-434 (Fernando Gómez Pomar \& Ignacio Marín García eds., Wolters Kluwer, 2015).

Rafael García López, Responsabilidad civil por daño moral: Doctrina y jurisprudencia (Bosch, 1990).

Ralf Michaels, The Functionalist Method of Comparative Law, en The Oxford Handbook of Comparative Law, 340-381 (Mathias Reimann \& Reinhard Zimmermann eds., Oxford University Press, 2006).

Ramón Daniel Pizarro, Daño moral (Editorial Hammurabi, 1996).

Ramón Daniel Pizarro \& Carlos Gustavo Vallespinos, Tratado de responsabilidad civil (Tomo I, Parte General Rubinzal, 2017).

Ramón Domínguez Águila, La acción por daño moral es intransmisible a los herederos de la víctima directa, LXXIV Revista de Derecho Universidad de Concepción, 219-266 (2006).

Ramón Domínguez Águila, Sobre la transmisibilidad de la acción por daño moral, 31 Revista Chilena de Derecho, n. ${ }^{\circ}$ 3, 493-514 (2004). https://dialnet.unirioja.es/descarga/articulo/2650455.pdf

René Ramos Pazos, De la responsabilidad extracontractual (Legal Publishing, 2008).

Sergio Cavalieri Filho, Programa de responsabilidade civil (8.. edición, Atlas, 2009).

Study Group on a European Civil Code \& Reseach Gropus on EC Private Law (Acquis Group), Principles, Definitions and Model Rules of European Private Law. Draft Common Frame of Reference (DCFR), (Outline Edition, Sellier, Munich, 2009).

Tomás Cano Campos, La transmisión mortis causa del derecho a ser indemnizado por los daños no patrimoniales causados por la Administración, 191 Revista de Administración pública, 113-157 (2013). https://recyt.fecyt.es/index.ph $\mathrm{p} / \mathrm{RAP} /$ article/view/40279

\section{Notas}

* Artículo de investigación

1 Ralf Michaels, The Functionalist Method of Comparative Law, en The Oxford Handbook of Comparative Law, 340-381 (Mathias Reimann \& Reinhard Zimmermann eds., Oxford University Press, 2006).

2 Co\#digo Civil de Chile [CC]. Ley de 14 de diciembre de 1855. Art. 1552. 1 de enero de 1857 (Chile). 
3 Manuel Barría Paredes, Algunos aspectos que plantea la tesis de la transmisibilidad de la acción indemnizatoria por daño moral, en Estudios de Derecho Civil XIII, 673-688 (Claudia Bahamondes Oyarzún, Leonor Etcheberry Court \& Carlos Pizarro Wilson eds., Thomson Reuters, 2018).

4 Fernando Pantaleón Prieto, La indemnización por causa de lesiones o de muerte, 42 Anuario de Derecho Civil, n. ${ }^{\circ}$ 2, 646-647 (1989). No obstante, Rodríguez Guitián hace referencia a autores alemanes que han puesto de relevancia que en la actualidad "se beneficia más a quien priva de la vida a una persona que a quien solamente se le causa lesiones, ya que en este último caso sí que cabe la reparación a la víctima”; ver Alma M. Rodríguez Guitián, Indemnización por causa de muerte: análisis de los ordenamientos jurídicos inglés y español, 2 Indret, n. ${ }^{\circ}$ 7, 1-53 (2005).

5 Si bien no existe total claridad en la doctrina y jurisprudencia chilena sobre quiénes tendrían legitimación activa para demandar el daño por repercusión o rebote. Véase Claudia Mejías Alonzo, Posibles límites al daño por repercusión o rebote, en Estudios de Derecho Civil X, 873-888 (Álvaro Vidal Olivares, Gonzalo Severín Fuster \& Claudia Mejías Alonzo coords., Thomson Reuters, 2015); Fabián Elorriaga De Bonis, Novedades judiciales en torno al daño moral por repercusión, en Estudios de Derecho civil IX, 229-245 (Hernán Corral Talciani \& María Sara Rodríguez Pinto coords., Abeledo Perrot, 2011).

6 Sin perjuicio de lo anterior, en Chile se ha planteado que incluso en casos de muertes instantáneas o inmediatas, la acción de la víctima para demandar el daño moral propio también se transmite, ya que "aun cuando exista una fracción ínfima de tiempo, el hecho fue anterior a su consecuencia y el difunto alcanzó a adquirir el derecho a ser indemnizado, el mismo que trasmite a sus herederos"; Pablo Rodríguez Grez, Responsabilidad extracontractual, 366 (2.. ed., Editorial Jurídica de Chile, Santiago, 2010). En el derecho comparado, puede citarse el caso del derecho portugués que permite la transmisibilidad de la acción incluso en casos de muerte instantánea en el artículo $496 \mathrm{~N}^{\circ} 3$ de su Código Civil. También se ha planteado en el derecho colombiano, en Javier Tamayo Jaramillo, Tratado de responsabilidad civil, 995 (2.. ed., Legis, 2007) (“[a]dicionalmente, el juez podría conceder indemnización por el daño extrapatrimonial derivado de la simple pérdida de la vida”).

7 Es importante tener en cuenta esta distinción, que puede conducir a errores en la resolución de casos concretos, como ocurrió en Fuentes con Gómez, C.A. de Santiago, 02/12/2013, Rol N $2704-2012$, CL/JUR/2806/2013, donde la Corte de Apelaciones de Santiago claramente confunde ambos tipos de daño moral: "en el caso que nos ocupa la acción se ha deducido por los herederos del trabajador fallecido, como 'víctimas por repercusión' que están invocando su calidad de herederos, reclamando entonces el daño sufrido por éste-cónyuge y padre- y, que se ha transmitido a ellos en cuanto sucesores universales, demandan entonces, lo que se denomina "iure hereditatis"' (cons. $\left.2^{\circ}\right)$.

8 Sin embargo, Barros discrepa de esta postura, ya que considera que "la prosecución de la acción iure hereditatis excluye o neutraliza los efectos de la acción ex iure propio". Enrique Barros Bourie, Tratado de responsabilidad extracontractual, 974 (Editorial Jurídica de Chile, 2006).

9 Miquel Martín Casals \& Josep Solé Feliú, El daño moral, en Derecho privado europeo, 857-881 (Sergio Cámara Lapuente coord., Colex, 2003). En el mismo sentido, Pilar Domínguez Martínez, Daño moral derivado de muerte y de lesiones corporales, en El daño moral y su cuantificación, 330 (Fernando Gómez Pomar \& Ignacio Marín García eds., Wolters Kluwer, 2015).

10 Debemos destacar como referencia en este punto el estudio de Medina Crespo, quien añade que cuando el crédito resarcitorio no sólo está reconocido y cuantificado, sino que ya se ha realizado e incorporado al patrimonio, en estricto rigor no nos encontramos ante un problema de transmisión del crédito resarcitorio, sino ante unos bienes que como realización del crédito se han incorporado ya al patrimonio del perjudicado. Ver Mariano Medina Crespo, Transmisibilidad hereditaria del crédito resarcitorio por daños corporales (Bosch, 2013).

11 Hernán Corral Talciani, Lecciones de responsabilidad civil extracontractual, 357 (2. ${ }^{a}$ ed., Thomson Reuters, 2013); Cristián Aedo Barrena, Responsabilidad extracontractual, 612 (Librotecnia, 2006); Enrique Barros Bourie, op. cit., 943.

12 Arturo Alessandri Rodríguez, De la responsabilidad extracontractual en el derecho civil chileno, 337-339 (Editorial Jurídica de Chile, 2005). En contra de esta interpretación se pronuncia Barros, quien sostiene que el artículo 2315 mal podría distinguir entre daños patrimoniales y extrapatrimoniales porque el Código Civil no contemplaba la categoría del daño moral como daño indemnizable. Enrique Barros Bourie, op. cit., 945.

13 Señala este autor que en un primer momento se intentó limitar la indemnización por daño moral sólo a aquellos daños tipificados legalmente (idea tradicional alemana). Posteriormente, se niega la indemnización de los daños morales puros, no es lo puramente moral sino la repercusión económica y por ello a la necesidad de supeditarlo a una pérdida material, corporal... Y actualmente se niega la transmisibilidadmortis causa porque el daño moral es personalísimo y se afirma que la persona puede "monetizar sus lágrimas, pero que el valor de su consuelo (su satisfacción económica) sólo ella puede aprovecharlo". El último paso 
consiste en afirmar que sólo se transmite mortis causa a los herederos si su titular fallece después de haberlo ejercitado; Mariano Medina Crespo, op. cit.,73-81.

14 Los principales defensores actualmente en el ordenamiento chileno de esta teoría serían Ramón Domínguez Águila, Sobre la transmisibilidad de la acción por daño moral, 31 Revista Chilena de Derecho, n. ${ }^{\circ} 3$, 493-514 (2004); Ramón Domínguez Águila, La acción por daño moral es intransmisible a los herederos de la víctima directa, LXXIV Revista de Derecho Universidad de Concepción, 219-266 (2006); Enrique Barros Bourie, op. cit., 945-947; y Hernán Corral Talciani, Lecciones de responsabilidad civil extracontractual, op. cit., 357-358.

15 Sobre la función satisfactiva de la indemnización del daño moral, véase Fernando Fueyo Laneri, Instituciones de derecho civil moderno, 111 (Editorial Jurídica de Chile, 1990).

162 Carmen Domínguez Hidalgo, El daño moral, 733 (Editorial Jurídica de Chile, 2000).

17 Ramón Domínguez Águila, Sobre la transmisibilidad de la acción por daño moral, op. cit., 513.

18 Fernando Fueyo Laneri, De nuevo sobre el daño extrapatrimonial y su resarcibilidad, 121 (Universidad de los Andes, 1972).

19 Enrique Barros Bourie, op. cit., 946-947, sustenta este argumento con en el hecho de que muchas jurisdicciones que admiten la transmisibilidad de la acción indemnizatoria del daño moral no permiten o limitan la indemnización de las víctimas por rebote. En la misma línea también se pronuncia Hernán Corral Talciani, Una vez más sobre la transmisibilidad del daño moral [en línea], El Mercurio Legal, (11 de enero, 2017).

20 "sólo si se tiene la indemnización del daño moral como una pena civil, habría razón para estimar que la sanción civil deba seguir al mayor de los males" Enrique Barros Bourie, op. cit., 944; Mariano Yzquierdo Tolsada, Sistema de responsabilidad contractual y extracontractual, 378 (Dykinson, 2001).

21 Mariano Medina Crespo, op. cit., 88.

22 En los considerandos $10^{\circ}, 12^{\circ}$ y $15^{\circ}$ de la citada sentencia se afirma el carácter personalísimo de la indemnización por daño moral y que su transmisibilidad a los herederos de la víctima desvirtuaría su naturaleza reparatoria, por lo que la muerte de la víctima, haya o no demandado la indemnización, traerá consigo su extinción. Corte Suprema de Chile. Rol n. 309-2006. "Porman Barahona con Pesquera Bío Bío S.A.”, 27 de junio de 2007.

23 Corte Suprema de Chile. Rol n. ${ }^{\circ}$ 4670-2017. “Culaciati Erwenne con Muñoz Barrientos”, 30 de agosto de 2017.

24 En dichos votos particulares los mencionados ministros sostuvieron que “1. (...) la acción por el daño moral tiene un carácter personalísimo, toda vez que persigue compensar el mal soportado por la víctima personalmente y la circunstancia de existir un vínculo entre la acción y el resarcimiento pretendido que es de carácter pecuniario no obsta a la antedicha conclusión, por cuanto el resarcimiento se genera y justifica en la aflicción de la víctima, lo que le confiere el carácter de personalísimo". Lo expuesto "no logra desvirtuarse con el hecho que dé lugar a un crédito en dinero, pues aún integrado dicho elemento patrimonial, el sentido y contenido de la pretensión cuestionada sigue inalterable, ya que lo que ella persigue es compensar el mal soportado por la víctima”. Además, se añade: “(...) el interés que protege la acción indemnizatoria no es puramente económico, de modo que el daño sufrido por el causante no se identifica con el sufrido por los herederos, sin perjuicio del derecho de estos últimos a demandar su propio daño”.

25 "Conviene no confundir la naturaleza extrapatrimonial y personalísima del interés espiritual afectado, con la naturaleza que asume el derecho a obtener reparación del daño derivado de dicha lesión. Esta última (...) tiene contenido patrimonial, sin que obste a esta conclusión la circunstancia de que los intereses lesionados se ubiquen fuera del patrimonio del damnificado”. Ramón Daniel Pizarro, Daño moral, 247-248 (Editorial Hammurabi, 1996).

26 En este sentido, Medina Crespo plantea una interesante analogía con el derecho de alimentos, afirmando que “(...) El derecho de alimentos (derecho personalísimo) es al crédito por las cuotas atrasadas (crédito ordinario), como el derecho a la integridad psicofísica (derecho personalísimo) es al crédito resarcitorio por los daños causados en ella (crédito ordinario). Por ello, la previsión normativa de la transmisibilidad de las cuotas atrasadas en concepto de alimentos (dado que no es excepcional), puede esgrimirse como argumento analógico para encontrar un concreto fundamento normativo a la transmisibilidad hereditaria de los créditos resarcitorios derivados del daño corporal". Ver Mariano Medina Crespo, op. cit., 72, 89 y 90.

27 Adriano De Cupis, El daño: Teoría general de la responsabilidad civil, 668 (2.. ed., Bosch, 2011).

28 Mariano Medina Crespo, op. cit., 90 (2013). 
29 En Chile, véase Fernando Fueyo Laneri, Instituciones de derecho civil moderno, op. cit., 111; y Pablo Rodríguez Grez, op. cit., 341-342. Para un panorama general sobre el derecho europeo, ver Cornelis C. Van Dam, European Tort Law, 349-353 (2.. ed., Oxford University Press, 2013).

30 Sobre esta jurisprudencia, véase Esteban Pereira Fredes, Un alegato a favor de las consideraciones punitivas en el derecho privado, Revista de Derecho Escuela de Postgrado, n. ${ }^{\circ}$, $61-78$ (2015).

31 Ramón Domínguez Águila, Sobre la transmisibilidad de la acción por daño moral, op. cit., 511.

32 Ramón Daniel Pizarro, op. cit., 245.

33 Aunque la afirmación la hace en relación con la indemnización por causa de muerte, ya de Castro destacó que en estos casos no se trata de justificar la adquisición del heredero, pues este tiene su propia causa en el título hereditario, sino la causa de adquisición respecto de la propia víctima. Justificada la indemnización del daño no patrimonial respeto de la víctima, la tienen también respecto de sus herederos. Ver Federico de Castro y Bravo, La indemnización por causa de muerte, 1956 Anuario de Derecho Civil, n. 2 , 451-504 (1956).

34 Lo cual algunos de estos autores intentan solucionar, proponiendo, en el caso de Corral, que coherentemente no se transmita la acción a los herederos incluso si la víctima hubiese interpuesto la acción respectiva antes de morir (Hernán Corral Talciani, Lecciones de responsabilidad civil extracontractual, op. cit., 358), lo cual altera las reglas generales de transmisibilidad de las acciones y requeriría, al menos, de una reforma legal. Por su parte, Barros sostiene que "debiera entenderse que la prosecución de la acción iure hereditatis excluye o neutraliza los efectos de la acción iure propio" (Enrique Barros Bourie, op. cit., 947), pero sin otorgar un fundamento normativo que lo justifique.

35 Podemos destacar como autores que defienden dichas tesis Esther Gómez Calle, Los sujetos de la responsabilidad civil. La responsabilidad por hecho ajeno, en Tratado de Responsabilidad civil, 464-465 y 475-482 (L. Fernando Reglero Campos coord., Aranzadi, 2007); Hernán Corral Talciani, Lecciones de responsabilidad extracontractual (Editorial Jurídica de Chile, 2003); Hernán Corral Talciani, Concurrencia de acciones de responsabilidad civil contractual y extracontractual en los daños causados por accidentes de trabajo, 14 Revista Chilena de Derecho Privado, 106-107 (2010); Carmen Domínguez Hidalgo, op. cit., 741; y René Ramos Pazos, De la responsabilidad extracontractual, 111-113 (Legal Publishing, 2008).

36 Destaca en este punto von Wichmann Rovira q puntualiza oportunamente que en el caso de esta tesis de transmisibilidad limitada lo que se considera intransmisible no es el crédito, sino la facultad procesal de ejercitarlo o no. Ver 3 Gerardo Von Wichmann Rovira, La responsabilidad extracontractual o derecho de daños, en Instituciones de Derecho privado (Juan Francisco Delgado De Miguel coord., Civitas, Madrid, 2003).

37 Mariano Medina Crespo, op. cit., 95.

38 En este sentido, ver Ramón Domínguez Águila, Sobre la transmisibilidad de la acción por daño moral, op. cit., 497; Mariano Medina Crespo, op. cit., 97-99 (2013); y Manuel Rebolledo Puig, Capacidad, representación y legitimación del reclamante en el proceso administrativo de responsabilidad patrimonial, 16 Revista Española de la Función pública, 77 (2011).

39 Tomás Cano Campos, La transmisión mortis causa del derecho a ser indemnizado por los daños no patrimoniales causados por la Administración, 191 Revista de Administración pública, 113-157 (2013); Manuel Rebolledo Puig, op. cit., 77.

40 Federico Navia Arroyo, Del daño moral al daño fisiológico ¿Una evolución real?, 4 Ensayos, 118 (2000).

41 Fernando Fueyo Laneri, Instituciones de derecho civil moderno, op. cit., 113; Carmen Domínguez Hidalgo, op. cit., 162. En el mismo sentido, podemos citar los baremos legales para indemnizar daños personales por accidente de tráfico en España, o en Italia los denominados "índices de relevancia" para cuantificar el resarcimiento por daño no patrimonial, o las propuestas en la Unión Europea de baremos para indemnizar daños corporales. Ver Miquel Martín Casals, Conceptos prejudiciales (heads of damage) en la indemnización por muerte y lesiones personales en Europa, 2 Indret, 1-48 (2013); y Tomás Cano Campos, op. cit., 146.

42 Así, en el fundamento jurídico decimotercero se señala: "Que, si bien el tema relativo a la transmisibilidad de la acción por daño moral no es de solución pacífica, en aquellos casos en que la víctima fallece luego de haber ejercido la acción procesal, tal como se ha expuesto, la mayoría de la doctrina se ha inclinado por considerar que ella puede transmitirse a sus herederos, tesis que a juicio de esta Corte resulta acertada. Es indudable que en el caso sub lite la demandante Rosa E.E.C. acreditó haber sufrido detrimento, angustia, dolor, sufrimiento, aflicción o menoscabo psicológico a raíz de la muerte de su cónyuge y, si bien esta litigante falleció antes de que se dictara la sentencia definitiva de primer grado, al haber ejercido la acción indemnizatoria en vida incorporó en su patrimonio este derecho de carácter litigioso. Por ende, el carácter personal de la acción resarcitoria no obsta a que ella pueda ser 
transmitida a sus herederos si la víctima la ejerce en vida, pero fallece durante la tramitación del pleito". Corte Suprema de Chile. Rol n. ${ }^{4} 4670-2017$. “Culaciati Erwenne con Muñoz Barrientos”, 30 de agosto de 2017.

43 Código Civil Federal de México. Decretos de 7 de enero y 7 de diciembre de 1926, y 3 de enero de 1928 (México).

44 Código Civil y Comercial Unificado de la Nación. Ley 26994 de 2014.7 de octubre de 2014 (Argentina).

45 Ramón Daniel Pizarro \& Carlos Gustavo Vallespinos, Tratado de responsabilidad civil, 194 (Tomo I, Parte General Rubinzal, 2017).

46 En el ámbito comparado destaca la recopilación de doctrina favorable a esta tesis realizada por Mariano Medina Crespo, op. cit., 103-108.

\section{Tomás Cano Campos, op. cit., 139.}

48 Sobre este punto relativo a la función resulta relevante el estudio de Fernando Pantaleón Prieto, Diálogo sobre la indemnización por causa de muerte, 36 Anuario de Derecho civil, n. 4, 1567-1585 (1983). Además, García López señala que incluso de defenderse la función de satisfacción personal de la propia víctima esto no sería obstáculo para admitir su transmisibilidad hereditaria, ya que en el caso de la transmisión mortis causa la satisfacción personal de la víctima puede encontrarse en el beneficio que los herederos obtienen del resarcimiento. Ver Rafael García López, Responsabilidad civil por daño moral: Doctrina y jurisprudencia, 200 y 212 (Bosch, 1990).

49 Concordamos con Medina Crespo cuando señala que “(...) quienes postulan la intransmisibilidad hereditaria del crédito resarcitorio por daños personales, participan, consciente o inconscientemente, de un prejuicio superado de signo romanista; se ajustan, consciente o inconscientemente a una concepción represiva de la responsabilidad civil; y, al tiempo, consciente o inconscientemente, adoptan una postura refractaria al resarcimiento del daño moral". Ver Mariano Medina Crespo, op. cit., 113-114.

50 Marcelo Barrientos Zamorano, Del daño moral al daño extrapatrimonial: La superación del pretium doloris, 35 Revista Chilena de Derecho, 85-106 (2008).

51 En el considerando $5^{\circ}$ de la sentencia, redactada por el abogado integrante Carlos Pizarro, se afirma lo siguiente: “(...) La acción, en cuanto cosa, es un bien, al que corresponde calificar como mueble o inmueble, según dispone el artículo 581 del Código Civil. Dado que lo que se busca es la indemnización en dinero cabe reputar la acción indemnizatoria como un mueble, la que constituye un bien que se encuentra en el patrimonio del causante desde que se verifican las condiciones para reclamar la indemnización por el daño moral ocasionado. No podría justificarse el rechazo a la transmisibilidad en la función del daño moral, pues como cualquier acción indemnizatoria lo que se busca con su ejercicio es el pago de una cantidad de dinero que refleje el daño ocasionado. La acción debiera en sí misma calificarse de personalísima para que no pudiera transmitirse”. (...) El asunto sobre el cual existe controversia, entonces, radica en qué razones pueden esgrimirse para justificar el carácter personalísimo de la acción indemnizatoria del causante. Si uno atiende a lo dispuesto en el artículo 1097 del Código Civil en relación al artículo 951 de ese cuerpo legal, el heredero representa a la persona del causante en todos sus derechos y obligaciones transmisibles. Debe, entonces, justificarse para la intransmisibilidad algún criterio que signifique excluir a la acción indemnizatoria específica para reclamar el daño moral del causante de aquellas transmisibles (...) Asignarle el carácter intransmisible a la acción, lo que constituye una excepción a la regla general, requiere un fundamento, que hasta el momento no se ha otorgado. Al referirse el artículo 88 de la Ley n. 16.744 - "los derechos concedidos por la presente ley son personalísimos e irrenunciables"- a los derechos que se confieren al trabajador se alude a aquellos de índole social, en particular las prestaciones médicas, por incapacidad, invalidez y por supervivencia, contempladas en el Título V, pero no alcanza a las acciones indemnizatorias previstas en el artículo 69. Lo contrario significaría que cualquiera sea la naturaleza del daño cuya indemnización se reclama, daño emergente o lucro cesante, no cabría la transmisibilidad, lo que atendido el artículo 2315 del Código Civil resulta impropio. No corresponde interpretar dicho precepto en el sentido que las acciones indemnizatorias serían personalísimas, debe por lo tanto limitarse al ámbito de aplicación a las prestaciones sociales de las cuales se ocupa la Ley No 16.744. “(...) Los hechos asentados en esta causa acreditan que la víctima directa no falleció en forma instantánea o de manera coetánea al accidente, sino transcurrió un lapso dado que su muerte sucedió tiempo después del contagio y durante el traslado a la ciudad de Santiago al haberse manifestado la enfermedad mientras se encontraba trabajando para la demandada en el sur de Chile. Asumiendo que el trabajador cuyos herederos reclaman el daño moral de causante sobrevivió al accidente, no hay inconvenientes dogmáticos que impidan aseverar la transmisión de la acción para reclamar la indemnización por el daño moral”. Corte Suprema de Chile. Rol n. 33990-2016. “Quezada Gallardo con Colmenares Warner Limitada”, 27 de diciembre de 2016.

52 Así en el considerando $6^{\circ}$ se establece que: "(...) Por otra parte el examen de lo resuelto demuestra que los sentenciadores, adhiriendo al criterio de transmisibilidad del daño moral en caso de muerte subsecuente de la víctima directa, aplicaron correctamente el objeto de esa trasmisión, refiriéndolo sólo a la indemnización del daño o quebranto moral que alcanzó a 
experimentar o sufrir la víctima directa antes de su fallecimiento y con algún grado de conciencia de ese detrimento, lo que probablemente aconteció al experimentar la impotencia y angustia de hundirse en la piscina y percibir el inicio de un proceso de asfixia hasta perder la conciencia. Y, posteriormente quizás, durante los procedimientos y tratamientos, inevitablemente invasivos, para reanimarla”. Corte Suprema de Chile. Rol n. ${ }^{\circ}$ 27842-2017. “Cárcamo Cárcamo con Ícono División Turismo S.A.”, 1 de marzo de 2018.

53 Para un estudio detallado sobre indemnización de daños por la Corte Interamericana de Justicia ver Jorge F. Calderón Gamboa, La reparación integral en la Jurisprudencia de la Corte Interamericana de Derecho Humanos: Estándares aplicables al nuevo paradigma mexicano (Instituto de Investigaciones Jurídicas, 2013).

54 En los Considerandos 35, 36 y 37 de dicha sentencia se establece: “(...) esta Corte considera que aun cuando una sentencia condenatoria, puede constituir en sí misma una forma de reparación y satisfacción moral, haya habido o no reconocimiento de responsabilidad por parte del Estado, en el presente caso, ésta no sería suficiente dada la específica gravedad de la violación al derecho a la vida y al sufrimiento moral causado a las víctimas y sus familias, las cuales deben ser indemnizadas conforme a la equidad. (...) Como esta Corte ya lo ha establecido, '[e]l daño moral infligido a las victimas...resulta evidente pues es propio de la naturaleza bumana que toda persona sometida a las agresiones y vejámenes mencionados experimente un sufrimiento moral. La Corte estima que no se requieren pruebas para llegar a esta conclusión'. Caso Aloeboetoe y otros. Reparaciones, supra 14, párr. 52). (...) De acuerdo con lo anterior la Corte, tomando en cuenta todas las circunstancias peculiares del caso, ha llegado a la conclusión que es de justicia conceder a cada una de las familias de los fallecidos y a cada uno de los sobrevivientes una indemnización de US $\$ 20.000,00$ ”. Corte Interamericana de Derechos Humanos. Caso Serie C No. 28. “El Amparo vs. Venezuela”, 14 de septiembre de 1996.

55 Así, en el considerando 56 de la sentencia se afirma: “(...) La Corte ha indicado, y lo reitera, que el derecho a la indemnización por los daños sufridos por las víctimas hasta el momento de su muerte se transmite por sucesión a sus herederos”. Y posteriormente en el considerando 84 se establece que: “(...) Al considerar y fijar las reparaciones por concepto de daño inmaterial, la Corte ha tomado en consideración las diversas clases de daños inmateriales a los que los representantes de la víctima y sus familiares y la Comisión han hecho referencia: los sufrimientos físicos y psicológicos padecidos por la víctima directa y los padecimientos físicos y psicológicos sufridos por los familiares de la víctima a causa de la detención, la tortura, la denegación de justicia, la falta de investigación de los hechos y de sanción a los responsables y el desconocimiento del paradero de los restos mortales del señor Trujillo Oroza”. Corte Interamericana de Derechos Humanos. Caso Serie C No. 92. “Trujillo Oroza vs. Bolivia”, 27 de febrero de 2002.

56 En este sentido, destaca las completas referencias bibliográficas y doctrinales realizadas por Mariano Medina Crespo, op. cit., 114-147. Realizando un pequeño resumen de lo allí expuesto por el citado autor, se destaca como en Derecho alemán inicialmente el daño moral era intransmisible, salvo que estuviera litispendente, pero desde la reforma de 1990 se admite sin restricción la transmisión hereditaria del crédito resarcitorio adquirido por daños morales. Por su parte el Derecho austriaco, también admite esta transmisión de los daños no patrimoniales a los herederos sin que se requiera que en vida el perjudicado reclamase o expresase su voluntad reclamatoria. En Derecho belga, la jurisprudencia señala que en los casos de muerte no instantánea de la víctima se produce la transmisión hereditaria del crédito resarcitorio adquirido por ella en vida. Por su parte, en el derecho francés que tanta influencia tuvo en Chile en sus inicios, los hermanos Mazeaud admitían de forma inequívoca la transmisibilidad del crédito resarcitorio adquirido por quien sufre daños patrimoniales y morales a sus herederos; sin embargo, un sector cualificado de la doctrina francesa se opuso firmemente a esta transmisión cuando los daños eran morales (Demogue/Dalloz/Rodiere), pero la jurisprudencia consolidó la transmisibilidad sin mayor problema. En Derecho griego, la transmisibilidad hereditaria del crédito resarcitorio se reconoce sólo en los casos que inicialmente se reconocía en Derecho alemán, es decir, sólo en aquellos casos en los que la víctima hubiera ejercitado, antes de morir, su acción resarcitoria. En Derecho holandés por regla general el daño moral es intransmisible, salvo que la víctima haya ejercitado su acción resarcitoria. En Derecho portugués (art. 496 del Código Civil), también se afirma la transmisibilidad de los daños al cónyuge y descendientes y en ausencia de éstos a los padres u otros ascendientes y por último a hermanos o sobrinos que los representen. En Derecho español, doctrina y jurisprudencia suelen considerar que la transmisibilidad de los créditos resarcitorios aparece expresamente reconocida en el ámbito de la responsabilidad civil automovilística, donde se compensan daños materiales y morales. En la doctrina hay discrepancias, pero la jurisprudencia suele admitir la transmisibilidad.

57 Paolo Sanna, The Recoverability of the Loss of the Right to Life per se: A Brief European Overview, 4 The Italian Law Journal, n. ${ }^{\circ}$ 1, 149-150 (2018). Agrega este autor que la jurisprudencia reciente de la Corte Constituzionale se ha abierto incluso a acoger acciones de los herederos cuando ha transcurrido un lapso de tiempo extremadamente corto entre el momento del ilícito y la muerte de la víctima. Paolo Sanna, op. cit., 152.

58 Edwin Peel \& James Goudkamp, Winfield \& Jolowicz on Tort, 743 (19.. ed., Sweet \& Maxwell, 2014). Nótese que esta suma es completamente independiente del monto fijo que las víctimas por rebote tienen derecho a demandar a título de "bereavement" por muerte accidental. Fatal Accidents Act 1976 s.1A. 
59 Study Group on a European Civil Code \& Reseach Gropus on EC Private Law (Acquis Group), Principles, Definitions and Model Rules of European Private Law. Draft Common Frame of Reference (DCFR), 3238-3239 (Outline Edition, Sellier, Munich, 2009).

60 European Group on Tort Law, Principios de Derecho europeo de la responsabilidad civil, 234 (traducción REDPEC, Martín Casals coord., Aranzadi, 2008).

61 Federico Navia Arroyo, op. cit., 115-120.

62 Javier Tamayo Jaramillo, op. cit., 987.

633 Jorge Gamarra, Tratado de Derecho Civil Uruguayo. Responsabilidad Extracontractual (Fundación de Cultura Universitaria, 2012).

64 Mário Moacyr Porto, Dano moral II, en Doutrinas Essenciais, 709-710 (Rui Stoco ed., Thomson Reuters, 2015); Sergio Cavalieri Filho, Programa de responsabilidade civil (8.. edición, Atlas, 2009).

65 En el caso chileno también ha sido controvertida la determinación del tribunal competente para conocer de dichas demandas, pues en la mayoría de los casos donde se reclama la transmisibilidad del daño moral por los herederos es por daños causados al fallecido en accidentes del trabajo. Así, en la actualidad se reclama tanto el daño de la víctima como el daño por rebote (indirecto) ante el Tribunal Laboral y en marco de una responsabilidad contractual y esto es seriamente cuestionable. Para un estudio de este aspecto procesal concreto, ver Hernán Corral Talciani, Concurrencia de acciones de responsabilidad civil contractual y extracontractual en los daños causados por accidentes de trabajo, op. cit., 89-105; y Manuel Barría Paredes, op. cit., 673-688.

66 En este sentido, Barría Paredes destaca que como la indemnización tiene carácter divisible (art. 1533.1 CC), en este caso tiene aplicación el inciso $4 .^{\circ}$ del artículo 1526, que indica que si los herederos obran conjuntamente deberían demandar el pago total de la deuda y no sumas separadas, ya que la justicia ordinaria no puede realizar la partición, por lo que el reparto procedente entre ellos se llevará a cabo por ellos de común acuerdo o por intervención de un juez partidor, siempre respetando las asignaciones forzosas. Ver Manuel Barría Paredes, op. cit.

67 Código de Procedimiento Civil de la República de Chile. Ley 1552 del 28 de agosto de 1902 (Chile).

68 Mariano Medina Crespo, op. cit., 150-161. En idéntico sentido también ver Tomás Cano Campos, op. cit., 154.

69 Considerando tercero de la sentencia de reemplazo de la Corte Suprema de 27 de diciembre de 2016 (Rol n. $\left.{ }^{\circ} 33990-2016\right)$.

70 Considerando sexto de la Sentencia de la Corte Suprema de 1 de marzo de 2018 (Rol n. $\left.{ }^{\circ} 27842-2017\right)$.

71 Respecto al tiempo, también se ha afirmado que si el dolor consciente, aunque sea corto es intenso y desmedido, podría indemnizarse. Vid. referencias citadas sobre esta materia en derecho inglés por Alma M. Rodríguez Guitián, op. cit., 10-11 (2005).

72 Audiencia Provincial Sección 1 de Soria (España). Sentencia 00013/2014, 14 de abril de 2014.

73 Pilar Domínguez Martínez, op. cit., 362.

74 Debemos tener presentes las referencias a la doctrina italiana sistematizada sobre esta materia por Medina y con las que concordamos. Ver Mariano Medina Crespo, op. cit., 180.

$75 \mathrm{Al}$ menos en el derecho francés y alemán. Cornelis C. Van Dam, op. cit., 365-366. Interesante sobre este punto resulta la postura del derecho inglés, que distingue entre el perjuicio de agrado [loss of amenity] y el pretium doloris.pain and suffering], siendo indemnizables en estos casos solo el primer tipo de daños, porque los segundos solo podrían existir al ser sentidos o experimentados. West \& Son v Shepard [1964] AC 326 (House of Lords). Algunas sentencias chilenas tendientes a decretar el daño moral en este tipo de casos pueden encontrarse en Cristián Aedo Barrena, Responsabilidad extracontractual, 489 (Librotecnia, 2006).

76 Por todos, véase Hernán Corral Talciani, Lecciones de responsabilidad civil extracontractual, op. cit., 160-161; Carmen Domínguez Hidalgo, op. cit., 716-718.

77 Cristián Aedo Barrena, op. cit., 505-506.

78 Advirtiendo, no obstante, que en este tipo de casos podría considerarse que no hubo un intervalo de tiempo suficiente entre el ilícito y la muerte como para generar auténticamente daño moral. En este sentido, siguiendo la jurisprudencia inglesa, 
podría entenderse que el ahogo y asfixia formaron parte del proceso mismo de la muerte. Véase más arriba nota 75 y texto que lo acompaña.

\section{Licencia Creative Commons CC BY 4.0}

Cómo citar este artículo: Susana Espada Mallorquín \& Alberto Pino Emhart, La transmisibilidad del crédito indemnizatorio por daño moral de la victima fallecida: análisis del caso chileno, 69 Vniversitas (2020). https: //doi.org/10.11144/Javeriana.vj69.tcid 